\title{
Flood Disaster Vulnerability Factors in Solok Selatan Regency
}

\author{
* Miftahuljannah ${ }^{1}$ and Amsyar Azim Ibrahim ${ }^{2}$ \\ ${ }^{1}$ The Graduate Students of Geography Education, Universitas Negeri Padang, Indonesia \\ ${ }^{2}$ NGO Investigator Researcher Centre for Disaster Management, Malaysia \\ Email : adek.210314@gmail.com
}

*Corresponding Author, Received: Februari 10, 2019, Revised: April 10, 2019, Accepted: May 10, 2019

This is an open acces article distributed under the Creative Commons 4.0 Attribution License, wich permits unrestricted use, Distribution, and reproduction in any medium provided the original work is properly cited @2017 by author and Universitas Negeri Padang

\begin{abstract}
The purpose of this research was to find the vulnerability factors of flood disaster in Solok Selatan Regency. This is a descriptive exploratory research, using primary and secondary survey as methods of data collection. The primary survey was done through semi structured interview with stakeholders, selected from government group. Secondary survey was conducted by institutional survey to obtain a general description of area and flood area in Solok Selatan Regency. To know the vulnerability factors of the floods, the researcher used an analysis technique called content analysis. The result showed that the factors of flood vulnerability in Solok Selatan were: high rainfall, poor drainage condition, slope, factor of road construction vulnerable to water, many meanders, factor of total population affected by floods, siltation caused by waste
\end{abstract}

Keywords: Vulnerability Factors, Flood Disaster, Solok Selatan Regency

\section{Introduction}

Indonesia is one of countries vulnerable to natural disaster. BNPB that about 2.500 natural disasters will hit Indonesia throughout 2019 (Hermon, 2012; Hermon, 2014; Hermon, 2015; Hermon et al., 2017). It is based on the data of disasters in 2018. According to BNPB Solok Selatan, most common disasters in Solok Selatan are of hydrometeorology, one of them is flood. Almost every area in Indonesia is affected by floods. One of them is Solok Selatan Regency. Flood is one of natural phenomenon caused by high rainfall intensity so the excess cannot be stored by drainage in an area. This condition results in pools in the area that can endanger the public (Hermon, 2001; Hermon, 2009; Hermon, 2010; Hermon, 2012; Oktorie, 2017). Flood is a natural disaster potential to damage and endanger people lives. This phenomenon is caused by high rainfall, so drainage cannot store it making the water to overflow Mudelsee et al., (2003); Hermon (2011); Hermon (2014); Oktorie (2018); Hermon (2019); Hermon et al., (2019) explained that the effect of deforestation on global climate change is accelerating hydrology cycle.

Solok Selatan Regency is located between the coordinates $01^{\circ} 17^{\prime} 13^{\prime \prime}$ and $01^{\circ} 46^{\prime} 45^{\prime \prime} \mathrm{S} ; 100^{\circ} 53^{\prime} 24^{\prime \prime}$ and $101^{\circ} 26^{\prime} 27^{\prime \prime}$ E, with an area of $3346,20 \mathrm{Km}^{2}$. Solok Selatan Regency is one of areas vulnerable to floods. Geographically, it is located 350-430 meters above sea level. The rainfall is quite high about 1.600-4.000 $\mathrm{mm} /$ year with $80 \%$ humidity. The Chief Executive of Regional Disaster management Agency (BPBD) Solok Selatan, Johny Hasan Basri, stated that at the beginning of 2019 some districts are affected by floods; Koto Parik Gadang Diateh District, Sungai Pagu District, and Pauah Duo District. The disaster was caused riber overflow water heavy rain. One of the local people said that there are six rivers overflowing at the districts. The rivers are Sapan Aia Angek River, Batang Pagu River, Batang Bangko River, Batang Suliti River, Batang Pulakek River and coal irrigation flow (BPBD of Solok Selatan Regency).

Based on those explanation, it can be said that Solok Selatan is vulnerable to flood disaster. At the beginning of 2019, precisely at the end of February, happened a flood quite disturbing the local people of Solok Selatan. Due to the flood, 449 houses were and 506 KK (families) or about 1,858 lives were affected. 
It cause done house, one school and 15 ha paddy fields submerged and 3 bridges collapsed. In addition, District Social Welfare Staff Coordinator (KTKS) of Solok Selatan, Reno Susi Sandra said, of thousands of people affected by the flood, there are 191 babies and toddlers. If this keeps happening without any effective managements, the disaster is going to give a bigger impact to the life sustainability of the local people. Therefore, it is important to know the causes of the floods by studying the vulnerability factors of flood in Solok Selatan.

\section{Method}

This research is a descriptive exploratory research which aimed to know the vulnerability factors of flood disaster. It employed 2 data collecting methods, primary data survey and secondary data survey. The first was collected directly from semi structured interviews with the stakeholders selected from the field. Then, Secondary data was obtained from institutional survey in the form of general description of the area and the flood area in Solok Selatan Regency. In order to know the vulnerability factors affecting flood in Solok Selatan Regency, the researcher used content analysis, a technique of data exploration relying on codes in a recording text. Literature study related to the topic was also conducted and the result was used for parameters of vulnerability variables in exploring data and information from selected stakeholders.

\section{Result and Discussion}

From the data obtained, the flood is divided into two categories, natural flood and human-induced flood. The vulnerability factors of flood in Solok Selatan are discussed according to the level of influence. The following picture is the map of the 2019 flood location in Solok Selatan.

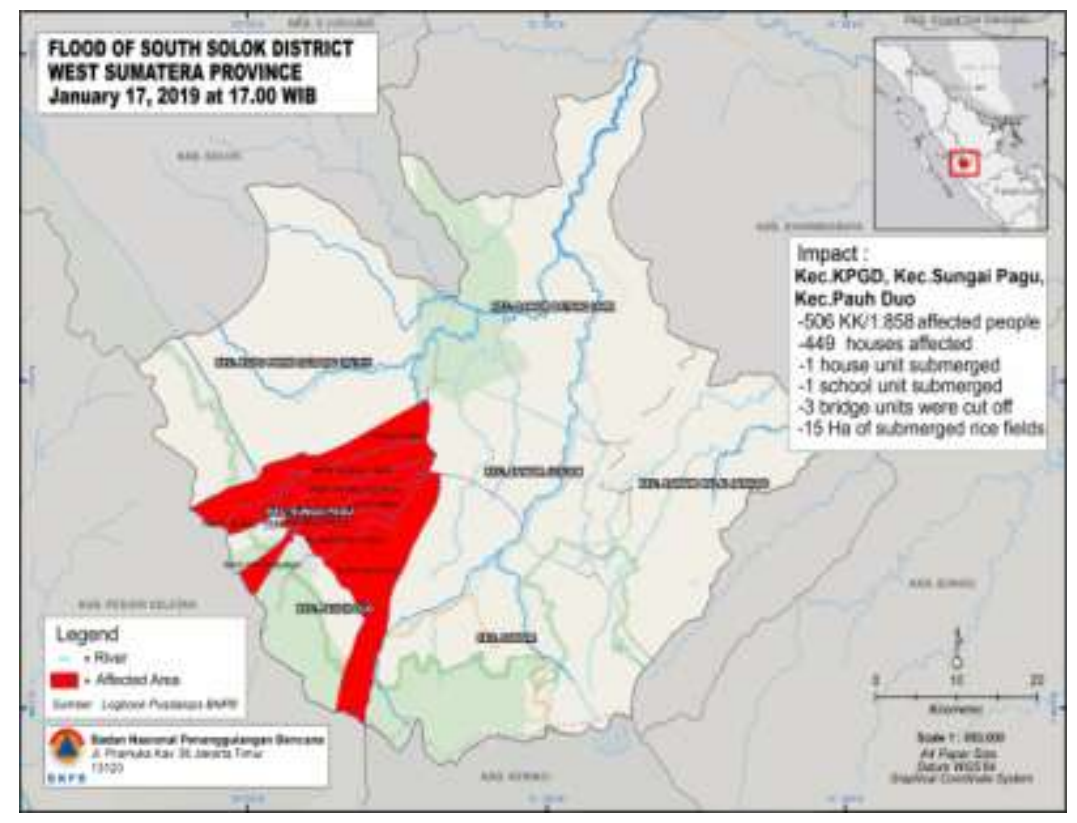

Figure 1. The Map of Studied Area

Source : Logbook Pusdalops BNPB (2018)

\section{High Rainfall}

High rainfall and long duration of rainfall are the main factors of flood vulnerability (Hermon, 2014; Hermon, 2016; Hermon et al., 2018). They made rivers overflow. And due to minimum absorbent area, the water cannot be stored. And vice versa. The lower the rainfall, the less vulnerable the area is to flood. The following table displays the data of rainfall in Solok Selatan Regency. 
Table 1. Data of Rainfall

\begin{tabular}{cll}
\hline No. & Description & Total \\
\hline 1. & Average rainy day & 14 days $/ \mathrm{month}$ \\
2. & Average rainfall & $174,83 \mathrm{~mm} / \mathrm{month}$ \\
\hline Source: &
\end{tabular}

\section{Poor Drainage Condition}

Dysfunctional drainage was one of the causal factors of flood in Solok Selatan (Hermon, 2016; Hermon et al., 2018). This condition was compounded by the amount of sedimentation and buildings in the affected areas. These caused the siltation of drainage resulting in decreased capacity of the drainage system, decreasing its ability to control the overflows caused by rain. Consequently, some areas in Solok Selatan especially Koto Parik Gadang Diateh District, Sungai Pagu District, and Pauah Duo District were submerged in water.

\section{Slopes}

Slope influences runoff, surface drainage, land use and erosion (Kristian and Oktorie, 2018). The more sloping an area is, the slower the runoff and it will cause inundations or floods. But, if the slope is steeper, the runoff is faster, so the rain will flow quickly and cause no inundation. In the table below are the arrangements of slope scoring.

Table 2. Data of Slopes

\begin{tabular}{llll}
\hline No. & Slope (\%) & Description & Height \\
\hline 1. & $0-5$ & Plain & $400-450$ masl \\
2. & $5-15$ & Small relief hills & $500-700$ masl \\
3. & $15-30$ & Medium relief hills & $600-800$ masl \\
4. & $30-50$ & Rugged relief hills & $650-900$ masl \\
5. & $50-70$ & Quite rugged relief hills & $800-1300$ masl \\
6. & 70 & Very rugged relief hills & $>1300$ masl \\
\hline
\end{tabular}

\section{Factor of Road Construction Vulnerable to Damage Due to Inundation.}

The factor of road construction vulnerable to inundation related damage describes that the roads are easily damaged by water pools and floods. Most of roads in Solok Selatan were damaged because of two factors. First, the road materials. Dominant material of road is asphalt. It is vulnerable to water causing damages on roads in Solok Selatan. More over, the location of local settlements is near rivers. So, the three districts in Solok Selatan were easily affected by floods causing the road damages such as potholes, uneven road and others. Such condition will certainly endanger riders and drivers passing the roads, including evacuation process of the flood victims.

\section{Meanders} cause floods.

Meanders cause the process of sedimentation. When heavy rain falls, the water will overflow and

\section{Factor of Total Population Affected by Floods}

This factor will affect the total potential flood victims. High population growth rate will influence the increase of potential number of flood victims (Hermon, 2016). The following table contains data of loss due to the 2019 floods in Solok Selatan. Five hundred and five KK (families) or about 1,858 lives became the victims of the disaster. It will increase the anxiety of people who live in the vulnerable area. 
Table 3. Data of Total Population Affected by Floods

\begin{tabular}{lllll}
\hline \multirow{2}{*}{ No } & \multirow{2}{*}{ Districts } & Loss & & Lives \\
\cline { 3 - 5 } & & House (unit) & KK & 211 \\
\hline $\mathbf{1}$ & Koto parik gadang di ateh & 48 & 59 & 1590 \\
$\mathbf{2}$ & Sungai pagu & 384 & 431 & 57 \\
$\mathbf{3}$ & Pauah duo & 15 & 15 & 5 \\
\hline
\end{tabular}

\section{Siltation Caused by Waste}

Floods are not always natural but also man-made. Man-made floods are majority caused by industrial waste or domestic waste. Therefore, waste management in community should be considered. If the people of Solok Selatan always throw their garbage to rivers, the rivers will be silted by the garbage. Silted rivers cont store the excessive water of heavy rain, causing it to overflow and affect the residents near the rivers.

\section{Conclusion}

According to the result of conducted analysis, the conclusion can be drawn from this article about flood disaster vulnerability factors in Solok Selatan Regency are: first, high rainfall factor(14 days/month; $174,83 \mathrm{~mm} / \mathrm{month})$. Second, dysfunctional drainage that could not store the excessive water from heavy rains. Third, Slope factor. The more sloping the area is, the lower the runoff is; and it could cause inundations and floods. And vice versa. Fourth, factor of poor road construction that could be easily damaged by inundations. If roads are damaged, floods will be highly possibly happened because the water is hardly absorbed by soil. Fifth, the factor of total population affected by floods. There were about 505 KK or 1,858 lives affected by the floods in 3 districts in Solok Selatan Regency. Sixth, factor of meanders or meandering rivers. This form easily causes sedimentation in river. When heavy rain falls, water in river will overflow. Seventh, river siltation caused by waste. If the local people always throw their garbage to river, river wil be slowly silted by the garbage.

\section{References}

Adhe, R. R dan A. Pamungkas. 2014, Faktor-Faktor Kerentanan yang Berpengaruh Terhadap Bencana Banjir di Kecamatan Manggala Kota Makassar, Institut Teknologi Sepuluh Nopember (ITS).

Fitria, C and F. Amalia. 2018. Society Perception Toward Flood Prevention in Sentosa Klang Park Selangor Malaysia. Sumatra Journal of Disaster, Geography and Geography Education, 2 (2), 39-46.

Hermon, D. 2001. Studi Kontribusi Penggunaan Lahan dan Vegetasi Terhadap Karakteristik Epipedon. Tesis Magister. Program Pascasarjana Universitas Andalas Padang.

Hermon, D. 2009. Dinamika Permukiman dan Arahan Kebijakan Pengembangan Permukiman pada Kawasan Rawan Longsor di Kota Padang. Disertasi. IPB Bogor.

Hermon, D. 2010. Geografi Lingkungan: Perubahan Lingkungan Global. UNP Press.

Hermon, D. 2012. Dinamika Cadangan Karbon Akibat Perubahan Tutupan Lahan Permukiman di Kota Padang Sumatera Barat. Forum Geografi: Indonesian Juornal of Spatial and Regional Analysis. Volume 26. Issue 1. p: 45-52. Uniiversitas Muhammadiyah Surakarta.

Hermon, D. 2012. Mitigasi Bencana Hidrometeorlogi: Banjir, Longsor, Degradasi Lahan, Ekologi, Kekeringan, dan Puting Beliung. UNP Press. Padang.

Hermon, D. 2014. Impacts of Land Cover Change on Climate Trend in Padang Indonesia. Indonesian Journal of Geography. Volume 46. Issue 2. p: 138-142. Fakultas Geografi Universitas Gajah Mada.

Hermon, D. 2014. Desain Kebijakan Tanggap Darurat dan Pemulihan Bencana Letusan Gunung Sinabung. Seminar Nasional Geografi. Master Program of Geography Education, Universitas Negeri Padang.

Hermon, D. 2015. Geografi Bencana Alam. Jakarta: PT RajaGrafindo Persada.

Hermon, D. 2016. Mitigasi Perubahan Iklim. Rajawali Pers (Radjagrafindo). 
Hermon, D. 2016. The Change of Carbon Stocks and CO2 Emission as the Result of Land Cover Change for Tin Mining and Settlement in Belitung Island Indonesia.Journal of Geography and Earth Science. Volume 4. Issue 1. p: 17-30.

Hermon, D. 2016. The Strategic Model of Tsunami Based in Coastal Ecotourism Development at Mandeh Regions, West Sumatera, Indonesia.Journal of Environment and Earth Science. Volume 6.

Hermon, D. 2017. Climate Change Mitigation. Rajawali Pers (Radjagrafindo).

Hermon, D., P. Iskarni., O. Oktorie and R. Wilis. 2017. The Model of Land Cover Change into Settlement Area and Tin Mining and its Affecting Factors in Belitung Island, Indonesia. Journal of Environment and Earth Science. Volume 7 No. 6. p: 32-39. IISTE.

Hermon, D., Ganefri., A. Putra and O. Oktorie. 2018. The Model of Mangrove Land Cover Change for the Estimation of Blue Carbon Stock Change in Belitung Island-Indonesia. International Journal of Applied Environmental Sciences. Volume 13. Issue 2. p: 191-202. Research India Publication.

Hermon, D., A. Putra and O. Oktorie. 2018. Suitability Evaluation of Space Utilization Based on Enviromental Sustainability at The Coastal Area of Bungus Bay in Padang City, Indonesia. International Journal of GEOMATE. Volume 14. Issue 41. p: 193-202. Geomate International Society.

Hermon, D. 2019. Evaluation of Physical Development of The Coastal Tourism Regions on Tsunami Potentially Zones in Pariaman City-Indonesia. International Journal of GEOMATE. Volume 17. Issue 59. p: 189-196. Geomate International Society.

Hermon, D., Ganefri, Erianjoni, I. Dewata, P. Iskarni and Alexander Syam. 2019. A Policy Model of Adaptation Mitigation and Social Risks The Volcano Eruption Disaster of Sinabung in Karo Regency-Indonesia. International Journal of GEOMATE. Volume 17. Issue 60. p: 190-196. Geomate International Society.

Husna, C. 2012. Faktor-Faktor yang Mempengaruhi Kesiapsiagaan Bencana di RSUDZA Banda Aceh, Bagian Keilmuan Keperawatan Medikal Bedah PSIK-FK Universitas Syiah Kuala, Banda Aceh.

Kristian, A and O. Oktorie. 2018. Study of Coastal Mangrove Conservation in the World. Sumatra Journal of Disaster, Geography and Geography Education. Volume 2. Issue 1. p: $49-52$

Oktorie, O. 2017. A Study of Landslide Areas Mitigation and Adaptation in Palupuah Subdistrict, Agam Regency, West Sumatra Province, Indonesia. Sumatra Journal of Disaster, Geography and Geography Education. Volume 1. Issue. 1. p: 43-49. Master Program of Geography Education.

Oktorie, O. 2018. Model Kebijakan Responsif Pemulihan Bencana Letusan Gunung Sinabung. Jurnal Kapita Selekta Geografi. Volume 1. Issue 1. p: 15-20 